\title{
Estudos
}

\section{Educação e Trabalho: a Contribuição de Marx, Engels e Gramsci à Filosofia da Educação}

\author{
Lilian Maria Paes de Carvalho Ramos \\ Universidade Católica de Petrópolis-RJ
}

Cotejando textos das obras de Marx e Engels com a produção de Gramsci, busca levantar os princípios democráticos básicos da educação. Defendidos por autores de tendências ideológicas diversas e com objetivos distintos, esses princípios, particularmente os da politecnia, almejam não apenas um aprimoramento da formação de mão-de-obra requerida pela sociedade industrial, mas, acima de tudo, a construção de uma hegemonia da classe trabalhadora, ampliando a base da camada governante.

\section{Introdução}

Karl Marx e Friedrich Engels dedicaram-se pouco à questão educacional em seus escritos filosóficos, sociais e econômicos. Sua denúncia ao caráter classista da educação, todavia, representou um marco, um ponto de partida para a reformulação de teorias educacionais baseadas no princípio democrático de igualdade.

Suas idéias foram refutadas ou desenvolvidas por vários pensadores, dentre os quais sobressai Antônio Gramsci e sua análise sobre o papel da escola e dos intelectuais na formação da hegemonia do proletariado, efetivação de fato aquele princípio. 
Ao enfocar as principais idéias desses pensadores sobre a instituição escolar, não houve pretensão de esgotar o assunto, o que seria impossível, e sim cotejar algumas denúncias e soluções apontadas pelos autores com os princípios da escola para uma sociedade democrática. Tampouco menosprezou-se a contribuição de outros autores: a opção por esses apenas revela a preocupação com um aprofundamento de suas idéias.

Apesar de a democratização do ensino básico haver sido transformada em bandeira dos liberais na Revolução Francesa, esse princípio só encontrará respaldo oficial após a Revolução Industrial, como consequência da necessidade de formação de mão-de-obra especializada para as indústrias nascentes. Pensadores de diversas tendências defenderão o princípio, diferindo em seus objetivos. Enquanto os liberais almejam o aumento da produtividade pura e simples, os socialistas vislumbrarão na educação das massas uma etapa para a construção de uma hegemonia da classe trabalhadora, hegemonia essa que dificilmente será obtida sem a concorrência do ensino formal.

Não um ensino qualquer, igual ao difundido na escola tradicional, e sim um ensino politécnico, destinado a anular as diferenças de classe, as quais transformam a escola em agência dos interesses burgueses; uma educação baseada no princípio da escola unitária para todos, independentemente de sua classe social de origem, ou seja, verdadeiramente fiel ao princípio da escola democrática.

A primeira parte deste trabalho versa sobre Marx e Engels, e a segunda, sobre Gramsci. Na conclusão, buscar-se-á apontar algumas recomendações para um programa educacional, voltado para a efetivação do princípio democrático na esfera educacional.

\section{A contribuição de Marx e Engels}

Analisando de forma crítica as idéias liberais, anarquistas e socialistas, e cotejando essas idéias com a realidade social e educacional de seu tempo, Marx e Engels observaram alguns aspectos relativos à educação formal, ou à sua ausência, que merecem destaque. 
Uma de suas primeiras e principais críticas dirige-se ao embrutecimento e à deformação na manufatura, onde a divisão do trabalho reprime um mundo de instintos e capacidades produtivas. $\mathrm{O}$ indivíduo é mutilado e transformado no aparelho automático de um trabalho parcial. Aliás, Marx cita denúncia do próprio Adam Smith nesse sentido, no qual este recomenda o ensino popular como solução para o problema do empobrecimento do intelecto do trabalhador manual. E vai além: analisa o papel da ciência e conclui que a indústria moderna transformou-a "em uma força produtiva independente do trabalho, recrutando (o trabalhador) para servir ao capital" (Marx, K., Engels, E, 1985, liv. 1, v.4, cap.12).

Engels observa um aspecto positivo no trabalho fabril, o qual permite ao trabalhador manter e aguçar a sua inteligência: "a revolta contra a sorte e contra a burguesia (...), único sentimento que o trabalho lhes permite" (Engels, 1975b).

Marx, seguindo essa linha de raciocínio, declara que a consciência do trabalhador desenvolve-se pela superação de barreiras representadas pelo "nível de desenvolvimento das forças produtivas sociais, da circulação, da ciência, etc", as quais se lhe aparecem como alienação. Ou seja, o trabalhador se comporta diante das condições produzidas por ele mesmo como diante de uma riqueza alheia e causadora de sua pobreza".

Mediante suas relações teóricas e práticas (isto é, com e sem a concorrência da educação formal), realiza-se a universalidade do indivíduo. Este "encontra-se, pois, em condições de aprender sua própria história como um processo, de conceber a natureza, com a qual forma realmente corpo, de maneira científica" e de compreender que nenhuma situação é imutável. Esta passagem ressalta ainda a relativa importância atribuída por Marx à educação formal: ela, sozinha, não conduz à universalidade do indivíduo.

Marx acrescenta uma limitação ao processo de universalização, o qual, aparentemente, gera um impasse:

...é evidente que tudo isto exige o pleno desenvolvimento das forças produtivas como condição da produção: e preciso que as condições de produção determinadas (se) deixem aparecer como obstáculos ao desenvolvimento das forças produtivas (Marx, 1978b, cap.2). 
Em outras palavras, enquanto as forças produtivas não atingirem o pleno desenvolvimento, as condições materiais para a realização da mudança não estarão dadas, e ela não poderá ocorrer. Esta questão será abordada novamente adiante.

Sobre o recrutamento de crianças e adolescentes para o trabalho na indústria, Marx é taxativo: "qualquer que seja a forma em que se realize sob o reino do capital é simplesmente abominável". Como solução para a questão da necessidade da cooperação desses segmentos, propõe que a jornada de trabalho de crianças de 9 a 12 anos seja reduzida para duas horas diárias; dos 13 aos 15 anos, para quatro horas; e dos 16 a 17 anos, para seis, com uma hora para comida e descanso. As escolas elementares deverão iniciar a instrução das crianças antes dos 9 anos.

Caberá à sociedade a responsabilidade de defender os interesses das crianças proletárias, pois os pais são impossibilitados de fazê-lo pelo sistema social de acumulação capitalista que os transforma em "mercadores de escravos de seus próprios filhos". Para livrar estes dos efeitos nocivos do sistema, é necessário transformar a "razão social" em "força social", por meio de leis gerais. A sociedade não pode permitir que crianças e adolescentes sejam empregados na produção,

\begin{abstract}
a menos que se combine este trabalho produtivo com a educação. Por educação entendemos três coisas: 1. Educação intelectual; 2. Educação corporal, como a que se consegue com os exercícios de ginástica e militares; 3. Educação Tecnológica, que recolhe os princípios gerais e de caráter científico de todo o processo de produção c, ao mesmo tempo, inicia as crianças e os adolescente no manejo de ferramentas elementares dos diversos ramos industriais (Marx, 1978c).
\end{abstract}

Esta concepção revela a preocupação de Marx com o pleno desenvolvimento dos jovens por meio da educação intelectual, física e profissional. Sugere, em seguida, que o ensino seja graduado de acordo com a idade dos alunos, e que parte dos gastos com as escolas politécnicas seja coberta, com a venda dos produtos nelas produzidos. Desta forma, ele entende que a classe operária elevar-se-á acima das demais.

Nesse trecho, é possível observar a preocupação de Marx em evitar que os jovens recebam uma orientação profissional restrita, o que, além de 
empobrecer o seu intelecto, dificultaria a sua inserção futura no mercado de trabalho ou, no mínimo, diminuiria o seu valor nele. Vários argumentos são utilizados nesse sentido. Haveria um aumento da criminalidade, devido à inadequação do trabalhador para outros tipos de trabalho, por ocasião de mudanças nos processos produtivos. A "velha divisão do trabalho com suas peculiaridades rígidas" estaria mantida e o trabalhador estaria em permanente risco de ser dispensado ou incorporado aos sabor das oscilações do mercado, etc.

Embora reconheça ser a vinculação da instrução primária com o trabalho fabril um avanço, Marx considera não haver "dúvida de que a conquista inevitável do poder político pela classe trabalhadora trará a adoção do ensino tecnológico, teórico e prático, nas escolas dos trabalhadores". Para ele, esta transformação, culminando na "eliminação da velha divisão do trabalho", seria resultante do desenvolvimento das contradições geradas pela forma de produção industrial, cuja base técnica é revolucionária em si mesma (Marx, K., Engels, E, 1985, liv.1,v.4,cap.13).

Marx observa, ainda, um outro aspecto da questão: o custo da produção da força de trabalho. Para o capitalista interessa que ele seja o menor possível.

A partir dessa constatação, é possível entender a pressão dos empresários capitalistas no sentido de repassar à escola o custo de produção da força de trabalho de que necessitam. Essa pressão é clara, quando se analisa sua materialização na forma de leis, evidenciando a velha rixa entre liberais e socialistas. Aqueles tentando diminuir os seus custos de produção e o tempo de formação da sua mão-de-obra; estes insistindo na importância de uma formação politécnica, que não limite o trabalhador a uma única função, mas que o prepare para exercer vários tipos de trabalho. Gramsci irá aprofundar a questão da formação geral versus ensino profissional, como se verá adiante.

Antes, serão discutidas, porém, algumas contradições apontadas por Marx com referência às reformas educacionais e à utilização da escola para a formação de mão-de-obra. Observa ele, muito apropriadamente, que a indústria moderna substitui o trabalho complexo pelo simples; recruta crianças e adolescentes precocemente para o trabalho, levando ao fracasso a legislação escolar; e não leva em consideração o nível de instrução do operário na hora de pagar o seu salário. A simplificação das funções do operário conduz a uma 
ampliação na oferta de mão-de-obra no mercado, já que esta é praticamente equivalente em qualquer ramo, e, consequentemente, a uma redução geral dos salários (Marx, 1987).

Esta constatação leva a alguns questionamentos. Se o trabalho industrial prescinde da educação formal para o preenchimento da maior parte de seus cargos, a quem interessa a educação continuada da classe trabalhadora? Certamente que não ao capitalista, visto que ela afasta os jovens do mercado de trabalho, diminuindo assim o "exército de reserva" de mão-de-obra desqualificada e, portanto, barata. Uma educação escolar interessa, sim, à classe trabalhadora, e não apenas porque desenvolve o seu intelecto, mas porque abre também para ela novas perspectivas de trabalho e permite-lhe conscientizarse de sua exploração mais facilmente. Afinal, como afirma Engels, "a miséria não só ensina o homem a rezar; também o ensina a pensar e a atuar".

Para bem servir a esses interesses, a educação do futuro deverá ser estatal, laica, gratuita e obrigatória, conjugando a formação geral com a ginástica e o ensino tecnológico teórico e prático. Germinada no sistema fabril, esta educação será gerida pela comunidade e poderá libertar-se da "força ideológica da repressão", representada pelo Estado burguês e pela religião, tornando a ciência acessível para todos. Para facilitar esses objetivos, todo o material escolar necessário deverá ser distribuído gratuitamente, sob a administração dos professores. (Marx, A guerra, v. 1, p. 167).

Quanto ao conteúdo curricular, Engels defende o ensino da gramática da língua nacional, acrescida das "próprias formas extintas dessa língua" e das "línguas vivas e moitas aparentadas". Mostra-se, assim, contrário à substituição do grego e do latim pelas matemáticas puras e aplicadas. Manifesta-se igualmente contrário à retirada da aplicação prática futura da formação teórica escolar, destinando esta formação a uma finalidade meramente curricular (Engels, 1975a, cap.5).

A opinião de Marx sobre as escolas particulares é radical: para ele não passam de empresas capitalistas, tais como fábricas de salsichas, cujo único intuito é gerar lucros para seus donos (Marx, K., Engels, F., 1985, liv. 1, v.5, cap. 14). Não podem, portanto, defender os interesses das classes trabalhadoras, privilégio reservado às escolas públicas.

Se, contudo, a educação formal é necessária -"educação e trabalho produtivo andarão lado a lado" (Engels, 1978) -, esse trabalho produtivo deverá 
propiciar aos jovens experiências em todos os ramos da produção, "segundo as diversas necessidades sociais e suas próprias inclinações", dando a eles a oportunidade de "desenvolverem tanto os seus sentidos como suas aptidões (...) desaparecerá toda a diferença de classe" (Marx, 1978a). Esta formação politécnica deverá compensar os inconvenientes da atual divisão do trabalho, "que impede o alcance do conhecimento profundo de seu ofício aos seus aprendizes".

Finalmente, Marx observa que as mudanças na educação exigem mudanças mais profundas.

\begin{abstract}
A teoria materialista da mudança das circunstâncias e da educação esquece que as circunstâncias fazem mudar os homens e que o educador necessita, por sua vez, ser educado. Tem, portanto, de distinguir na sociedade as partes desta, uma das quais colocada acima dela (Teses, 1974).
\end{abstract}

O que leva, aparentemente, ao impasse aludido no início desta exposição. Se as mudanças na educação exigem que haja, primeiramente, mudanças nas circunstâncias, é preciso esperar que estas ocorram, para então realizar as mudanças necessárias na educação. Mas o próprio Marx indica como sair do impasse. Se,

por um lado, é necessário modificar as condições sociais para criar um novo sistema de ensino, por outro, falta um sistema novo para poder modificar as condições sociais. Consequentemente, é necessário partir da situação atual (Marx, 1978a).

Na conclusão, desenvolver-se-á o tema "partir da situação atual" do sistema de ensino, para levá-lo em direção a uma nova sociedade, na qual os interesses da classe trabalhadora, e não apenas da burguesia, sejam contemplados.

\title{
A contribuição de Gramsci
}

Seguidor inequívoco da tradição marxista, Gramsci centra sua obra no estudo das superestruturas.

Diferindo de Marx e Engels, os quais ocuparam-se do tema educativo apenas de passagem pela discussão de temas sociais mais amplos, Gramsci 
entrega-se a ele de forma bem mais aprofundada. E mais, distanciando-se dos outros pensadores marxistas e socialistas, realiza a "passagem da crítica negativa da escola burguesa e da política socialista à busca de realizações" na área de organização da cultura (Manacorda, 1990, p.33).

Gramsci propõe, no decorrer de sua obra, um princípio educativo baseado nas exigências do industrialismo e das modificações por ele introduzidas na vida social. Os novos rumos apontam para uma formação total do homem, nem presa ao humanismo estéril da escola burguesa nem ao profissionalismo estreito das escolas profissionalizantes, ou seja, coerente com as inovações técnico-científicas do mundo moderno. Vinculando definitivamente a pedagogia e a política, procura conciliar "o rigor metodológico próprio da fábrica e a abertura mental própria da exigência humanística" (idem, p.67).

Devido às características de sua obra, escrita de forma fragmentada nas cartas e em 29 cadernos do cárcere, foram escolhidos alguns temas para comentários. São eles: um novo princípio educativo, os intelectuais e a cultura, a organização escolar e a escola unitária.

\section{UMNOVO PRINCÍPIO EDUCATIVO}

Ultrapassando a mera crítica do sistema escolar burguês, Gramsci propõe que a escola incorpore um novo princípio educativo, o qual gerará mudanças profundas em sua organização. O princípio educativo, no seu entender, terá forçosamente de ser buscado nos princípios da produção industrial, na cultura do tipo americano; importa a criação de uma série de "hábitos psicofísicos", os quais deverão ser desenvolvidos em idade tenra, antes da puberdade, visto que, posteriormente, sua assimilação será bem mais difícil. Essa implantação dar-se-á de maneira coercitiva, porque

a vida na indústria exige um tirocínio geral, um processo de adaptação psicofísica para determinadas condições de trabalho, de nutrição, de habitação, de costumes etc, que não é inato, "natural", mas requer uma assimilação (Gramsci, 1978, p.391).

A adaptação é constante devido às levas de migrantes rurais que são expulsas do campo para o trabalho fabril e à emergência das novas gerações, que precisam ser educadas no novo sistema de trabalho (pela força ou pela 
persuasão). A "hegemonia da fábrica", baseada na racionalização, pede a elaboração de "um novo tipo humano", não apenas no aspecto físico, como também moral. A reprodução sexual passa a ser encarada como "função econômica" e uma nova "ética sexual", adaptada aos "novos métodos de produção e trabalho", precisa ser criada. Na América o "puritanismo" reflete essa preocupação, posto que

não é possível desenvolver o novo tipo de homem solicitado pela racionalização da produção e do trabalho, enquanto o instinto sexual não for absolutamente regulamentado, não for também ele racionalizado (idem, p.392).

Além do instinto sexual, os outros elementos de "animalidade" do homem carecem igualmente de sujeição. Esta sujeição é sempre uma imposição externa, tanto no industrialismo como em outros tipos de cultura.

A seleção ou "educação" do homem apto para os novos tipos de civilização, para as novas formas de produção e de trabalho, foi realizada com o emprego de brutalidades inauditas, lançando no inferno das subclasses os débeis e os refratários, ou eliminando-os, simplesmente (idem, p.393).

Uma vez atingida a hegemonia das ideologias puritanas, a pressão tende a ceder. Nos casos do taylorismo, essas ideologias atuam como coadjuvantes no processo de imposição de "uma rígida disciplina dos instintos sexuais, um reforçamento da família, a regulamentação e a estabilidade das relações sexuais", necessários ao modo de produção dominante (idem, p.394-395). Quando esta imposição recai apenas sobre algumas classes da sociedade, têm-se uma situação que Gramsci denomina de "hipocrisia social", na qual há imposição da virtude por pressão ou por convicção de uma classe sobre a(s) outra(s),

pois os novos métodos de trabalho estão indissoluvelmente ligados a um determinado modo de viver, de pensar e de sentir a vida; não é possível obter êxito num campo sem obter resultados tangíveis no outro (idem, p.396).

Gramsci ressalta, ainda, a inexorabilidade do processo de criação "de um tipo novo de trabalhador e de homem", sem qualquer relação com o homem pré-industrial, com a criação produtiva do artesão. 
O industrialismo esmaga a "humanidade e espiritualidade do trabalhador", forçando-o a um novo "equilíbrio psicofísico". Os altos salários são a forma utilizada na América para selecionar e manter os trabalhadores mais aptos e sem "vícios", resultando numa absorção da moral puritana pelas classes trabalhadoras, basicamente. Trata-se de uma combinação de coerção, persuasão e consentimento, destinada a permitir "um determinado nível de vida, capaz de manter e reintegrar as forças desgastadas pelo novo tipo de trabalho" (idem, p.405).

Gramsci aponta, ainda, para a relação entre os campos econômico, moral e intelectual, ao opor-se ao autodidatismo. Considera este "anemia de disciplina crítica e científica", "hilotismo", "desordem intelectual", "bohème", etc. Ou seja, o oposto das virtudes de ordem, coerência e disciplina, que são "postuladas como uma exigência objetiva do americanismo, isto é, do industrialismo" (apud Manacorda, 1990, p. 130-132).

Essa nova cultura, que está sendo implantada sob a égide da América, implica a "destruição da civilização existente" e o "nascimento de uma nova". A nova civilização a surgir será reconstruída "por aqueles que se acham no processo de criar, por imposição e através do próprio sofrimento, as bases materiais dessa ordem. Eles devem encontrar o sistema de vida original e não de cunho americano, para converter em liberdade aquilo que hoje é necessidade" (idem, p.272).

Será necessário um novo intelectualismo, desvinculado do humanismo tradicional e ultrapassado, para a tarefa de adequação do homem ao sistema de vida moderno. A tarefa requer uma ultrapassagem do mundo da produção, puro e simples. O estudo da questão deve ser feito a partir do ponto de vista da escola única do trabalho, ou seja, da educação como "instrumento através do qual a ordem social é introduzida na ordem natural" (idem, p.201 e 244). Nesta passagem é evidente a importância que Gramsci atribui à educação, bem maior do que aquela verificada em Marx, o qual não considerava a educação formal essencial para a universalização do indivíduo. É claro que o italiano refere-se não a uma educação tradicional, de cunho elitista, mas a uma "reforma intelectual e moral", ligada aos interesses da classe ainda subalterna, tarefa a ser desenvolvida por um novo tipo de intelectual, desvinculado dos interesses das classes dominantes tradicionais. E o ponto de referência para a mudança está no mundo do trabalho. 
O máximo utilitarismo deve ser a base de qualquer análise das instituições morais e intelectuais a serem criadas e dos princípios a serem difundidos. A vida coletiva e individual deve ser organizada, tendo em vista o máximo rendimento do aparato produtivo (idem, p.205-206).

Ou seja, os princípios do industrialismo devem ser impostos até se transformarem numa "segunda natureza" do homem moderno.

Ao relacionar "o modo de produção e o modo de viver", o "instrumental" e a "educação", Gramsci propõe "a identidade entre a organização científica do trabalho manual e do trabalho conceptual"; em outras palavras,

o trabalho industrial, que implica, do ponto de vista intelectual, o conhecimento das leis da natureza e da sociedade, e do ponto de vista moral, o hábito de um sistema de vida harmonicamente equilibrado, é, portanto, em última instância, o princípio educativo unitário que, marxianamente, Gramsci aponta (Manacorda, 1990,p.216e285).

Ou seja, Gramsci desdobra a concepção marxista de universalidade do indivíduo mediante a união das relações teóricas e práticas, do trabalho com o estudo. Seu princípio educativo importa a formulação de um novo e "moderno" conceito de cultura, a ser desenvolvido pelos intelectuais de diversas matizes e divulgado pelas vias de organização e divulgação culturais tradicionais e modernas.

\section{OS INTELECTUAIS E A CULTURA}

Gramsci possui uma visão ampla da cultura, ilustrada na famosa passagem sobre a natureza intelectual do trabalho no discurso sobre a formação dos intelectuais:

Não existe atividade humana da qual se possa excluir toda intervenção intelectual, não se pode separar o homo faber do homo sapiens. Em suma, todo homem fora de sua profissão desenvolve uma atividade intelectual, qualquer que seja; é um filósofo, um artista, um homem de gosto; participa de uma concepção de mundo; possui uma linha consciente de conduta, contribui, assim, para manter ou modificar uma concepção de mundo, isto é, para promover novas maneiras de pensar (Gramsci, 1989, p.8).

Antevisões dessa concepção de cultura podem ser encontradas em Americanismo e Fordismo e Outros Textos, embora não formuladas tão 
completamente. Estes pequenos trechos permitem-nos perceber que Gramsci considera toda e qualquer atividade humana intelectual,ou melhor, como tendo um aspecto intelectual, paralelo ao físico, como na seguinte passagem:

Não existe trabalho puramente físico...em qualquer trabalho físico, mesmo no mecânico e degradado, existe um mínimo de qualificação técnica, isto é, um mínimo de atividade intelectual criadora (idem, p.7).

Ou seja, não existe o "gorila amestrado" de Taylor. Mas Gramsci faz uma distinção importante entre todos os homens (intelectuais) e aqueles que desempenham na sociedade a função de intelectual. Dentre estes últimos destacam-se dois tipos de intelectuais: os tradicionais - eclesiáticos, aristocratas togados, administradores, cientistas, teóricos, filósofos etc-, os quais fazem parte de um continuam histórico e cujo meio de ser consiste na eloquência, e o novo tipo de intelectual, o orgânico; cuja formação será baseada na "educação técnica estreitamente ligada ao trabalho intelectual, mesmo ao mais primitivo e desqualificado". Este novo intelectual não mais se caracterizará pela eloquência e pelo distanciamento do mundo do trabalho físico, devendo "imiscuir-se ativamente na vida prática como construtor, organizador, pensador permanente (...), especialista mais político" (idem, p.8).

Um e outro são, importantes, todavia, para qualquer grupo social que busque o domínio, a hegemonia. Esse grupo precisará proceder, simultaneamente, à assimilação e à conquista "ideológica" dos intelectuais tradicionais e elaborar "seus próprios intelectuais orgânicos" (idem, p.9), cuja tarefa será adequar "a cultura prática" (Manacorda, 1990, p.205).

Prosseguindo na explicitação da cultura como conquista de "uma concepção superior", um modo de ser que determina uma forma de consciência, elaborada de forma ativa mediante a organização e capaz de intervir no desenvolvimento político e econômico, Gramsci aponta para "outras vias" de organização cultural, instrumentos de criação da língua nacional, que seriam coresponsáveis pela "elevação geral do nível cultural das massas subalternas", num desdobramento da tradição marxiana, e que são os seguintes: 1. a escola; 2. os jornais; 3 . os escritores de arte e os populares; 4. o teatro e o cinema sonoro; 5. o rádio; 6. as reuniões públicas de todos os gêneros; 7. as relações de "conversação" entre os vários estratos da população mais ou menos cultos; 8. os dialetos locais (apud Manacorda, 1990, p.22-24 e 227). 
Gramsci incorpora, ainda, elementos modernos à sua tentativa de tornar a ciência acessível a todos, deixando de ser um simples instrumento do capital. Além da escola, ele lista como partes integrantes do "material ideológico" da cultura a imprensa e "tudo quanto influi ou pode influenciar, diretamente ou indiretamente, sobre a opinião pública", como as bibliotecas, os currículos, os clubes, a arquitetura etc. Estes órgãos de hegemonia da classe dominante, hegemonia esta que o Estado exerce a seu favor por intermédio dos intelectuais (a "trama privada" do Estado), são colocados lado a lado com organizações políticas e sindicais. O Estado "educa o consenso" (apud Manacorda, 1990, p.125-126e 187-188).

O fato de a escola estar arrolada em primeiro lugar como via de organização cultural não é fortuito. Além de ser um instrumento de "luta contra o folclore, com todas as suas sedimentações tradicionais de concepções do mundo", substituindo essas crenças "pela aprendizagem (...) das leis da natureza (...) e das leis civis e estatais", Gramsci confere-lhe ainda maior importância:

A escola em todos os seus graus e a igreja são as duas maiores organizações culturais em todos os países, pelo número de pessoas que ocupam (idem, p.243 e 261-262).

Seus intelectuais, os padres e os professores, são os "mais numerosos e mais próximos da periferia". Uma vez mais, ele aproxima-se, aqui, da tradição marxista de luta pela diminuição da "força ideológica da repressão", representada pelo Estado e pela Igreja, mediante seus diversos órgãos, entre eles, a escola.

O aparato cultural é o responsável pela transmissão da herança do passado e de todos os seus valores instrumentais. Conquanto sua importância seja menor que no passado, a escola é

o instrumento para elaborar os intelectuais dos diversos níveis. A complexidade da função intelectual nos vários Estados pode ser objetivamente medida pela quantidade de escolas especializadas e pela sua hierarquização (Gramsci, 1989, p.9).

Para atingir essa meta, torna-se necessário aliar quantidade e qualidade e democratizar a seleção e a elaboração "das mais altas qualificações intelectuais", proporcionando, a par de uma refinada especialização técnico-cultural, 
a maior ampliação possível da difusão de instrução primária e a maior solicitude no favorecimento dos graus intermediários ao maior número (idem, p. 10).

Tem-se, novamente, nesta passagem, um desdobramento das idéias marxistas de universalização da educação e de ampliação da escolaridade das classes trabalhadoras, a fim de proporcionar a oportunidade para a sua conscientização, reforçada pela passagem seguinte:

A cultura é privilégio. A escola é um privilégio. E não queremos que seja assim. Todos os jovens deveriam ser iguais diante da cultura. O Estado não deve pagar com o dinheiro de todos a escola para os medíocres e deficientes, mas filhos dos abastados, enquanto exclui dele os inteligentes e capazes, porque filhos de proletários (idem, p.25).

Para Gramsci (1989, p.230), a escola possui uma função educativa positiva, e os tribunais, uma função educativa repressiva e negativa. Essas duas instâncias, aliadas a "outras iniciativas e atividades ditas privadas (...) formam o aparato da hegemonia política e cultural das classe dominantes". Ou seja, a relação pedagógico-política não será restrita à escola; ela permeia todas as relações sociais, sendo o Estado a expressão do equilíbrio entre a sociedade política e a sociedade civil.

Seguindo por esta via de raciocínio, Gramsci estuda a organização de uma escola capaz de atender às características da sociedade moderna e da "taylorização intelectual", sua condição necessária. Uma escola que se constitui, ao lado de outras agências culturais, "num serviço intelectual", assegurado "pelo Estado e pelas organizações locais". Como se vê, embora fiel à linha inaugurada por Marx e Engels, Gramsci amplia e desenvolve bastante a proposta inicial daqueles pensadores. Vejamos como ele concebe a organização de uma escola dessa natureza, contrapondo-a à escola italiana de seu tempo.

\section{A ORGANIZAÇÃO ESCOLAR}

Discutiremos, inicialmente, o caráter coercitivo da educação em Gramsci, já aludidas en passant no item sobre um novo princípio educativo. Expresso por vários termos - autoridade, conformismo, voluntarismo, - Gramsci (1989, 
p. 138) acredita ser o hábito uma segunda natureza, adquirida historicamente. E graças ao incorformismo que o automatismo se converte em liberdade e a liberdade em responsabilidade, pois,

o estudo é também um trabalho, e muito fatigante, (...) é um processo de adaptação, é um hábito adquirido com esforço, aborrecimento e mesmo sofrimento.

Esse sofrimento, comum a todos os alunos, é bem maior para aqueles que não recebem alimentação adequada nem hábitos familiares facilitadores da aprendizagem intelectual. Porém, é preciso não sucumbir à tendência a afrouxar a disciplina do estudo, a provocar facilidades, se se quiser criar uma nova camada de intelectuais no seio de "um grupo social que tradicionalmente não desenvolveu as aptidões adequadas". (idem, ibidem).

Desdobra-se, aqui, a idéia da necessidade de proporcionar educação para as crianças das classes trabalhadoras as quais, entregues à sua própria sorte, não desenvolverão as aptidões necessárias à vida na sociedade moderna. "Renunciar a formar a criança significa apenas permitir que sua personalidade se desenvolva extraindo caoticamente do ambiente geral todos os motivos de vida" (apud Manacorda, 1990, p.75). Ou seja, Gramsci rejeita o inatismo e enfatiza o papel da educação como adaptação da criança para a vida em sociedade.

O hábito do estudo, da "exatidão", da "concentração psíquica," precisa ser inculcado por "meio de coação mecânica" até os 14 anos.

Esta tarefa é da escola, mas não apenas dela. É preciso que todos os que têm contato com as crianças tratem-nas com seriedade, habituando-as ao "hilotismo", porque "toda geração educa a nova geração", adaptando-a à sua época. E o tempo da criança na escola é insignificante em face das outras influências recebidas do ambiente social mais amplo; ademais, seu efeito só se faz sentir a longo prazo (idem, p. 133).

A disciplina necessária ao trabalho intelectual "não anula a personalidade e a liberdade" do aluno, sendo um "elemento necessário de ordem democrática, de liberdade". Além do que, se a coerção social "se desenvolve segundo o desenvolvimento das forças sociais, não é coerção, mas 'revelação' de verdade cultural obtida por um método acelerado"(idem, p.257-259). 
A liberdade não deixa de existir nessa pedagogia, só que vem acompanhada "da responsabilidade que gera disciplina (...) a única liberdade é aquela que é responsável, isto é, universal, na medida em que se coloca como aspecto individual de uma liberdade coletiva ou de grupo. Como expressão individual de uma lei" (idem, p.211).

Para Gramsci (1989, p. 122 e 130), a escola elementar caracteriza-se por uma maior presença da disciplina, resultando num "conformismo dinâmico". A geração mais velha transmite à geração jovem o patrimônio do passado.

O conceito e o fato do trabalho (da atividade teórico-prática) é o princípio educativo imanente à escola elementar, já que a ordem social e estatal (direitos e deveres) é introduzida e identificada na ordem natural pelo trabalho. $\mathrm{O}$ aluno deverá atingir a compreensão da atualidade como síntese do passado, de todas as gerações passadas, que se projeta no futuro. É este o fundamento da escola elementar. Fundamento este que deverá ser desenvolvido ao lado do ensino das primeiras noções "instrumentais" da instrução (ler, escrever, fazer contas, geografia, história).

A partir do momento em que a escola se separou da vida, entrou em crise. Para superá-la, será preciso que a escola volte a se ligar à vida. Só assim haverá uma "participação realmente ativa do aluno na escola". O professor precisa, ademais, conscientizar-se "dos contrastes entre o tipo de sociedade e de cultura que ele representa e o tipo de sociedade e de cultura representado pelos alunos" (apud Manacorda, 1990, p.246-247).

E aprofunda mais a questão das diferenças culturais. $O$ professor precisa conhecer a psicologia popular, o folclore, respeitando o linguajar do aluno, sua espontaneidade inata. $\mathrm{O}$ oposto significa dificultar a aprendizagem da criança proveniente das classes populares e a consequente facilitação para os que falam a mesma linguagem da escola. Umas e outras, entretanto, precisam ser habituadas "ao trabalho metódico e disciplinado" e não podem ser deixadas "abandonados a si mesmas" (idem, p.61-65 e 209). É preciso ter em mente que

a consciência da criança não é algo individual (e muito menos individualizado), é o reflexo da fração da sociedade civil da qual participa (...). A consciência individual da esmagadora maioria das crianças reflete relações civis e culturais diversas e antagônicas às que são refletidas pelos programas escolares: o certo de uma cultura evoluída torna-se verdadeiro nos quadros de uma cultura fossilizada e anacrônica, não existe unidade entre escola e vida e, por isso, não existe unidade entre instrução e educação (Gramsci, 1989, p.131). 
A relação aluno-professor é analisada pelo autor como sendo ativa, de relações recíprocas e, portanto, todo professor é sempre aluno e todo aluno, professor. Além do fato de que "o aluno não é um disco de vitrola, não é um recipiente passivamente mecânico". Mas o autor toma o cuidado de não limitar a relação pedagógica ao contexto professor-aluno, enxergando-a em "todo indivíduo com referência aos outros indivíduos, entre camadas intelectuais e não-intelectuais, entre governantes e governados, entre elites e seguidores, entre dirigentes e dirigidos, entre vanguarda e corpos de exército" (apud Manacorda, 1990, p.252-254).

O trabalho vivo do professor é enfatizado por representar "o nexo instrução-educação", devendo ele ser consciente não só dos contrastes entre a sociedade e a cultura que ele representa em face da cultura do aluno; bem como de sua tarefa de "acelerar e disciplinar a formação da criança conforme o tipo superior em luta com o tipo inferior"(Gramsci, 1989, p. 131).

Os trechos seguintes revelam a importância atribuída pelo autor ao corpo docente, considerado "uma expressão da consciência civil de toda a nação", ainda que "amesquinhada, e não certamente uma vanguarda" (apud Manacorda, 1990, p.244).

Enfatizando a recomendação marxista de que "é preciso educar os educadores", reconhece que

mesmo os métodos mais fascinantes tornam-se ineficientes se faltam as pessoas capazes de vivificá-los em todos os momentos da vida escolar e extra-escolar; fracassam devido à deficiência dos professores (idem, p.97).

\section{E arremata:}

se o corpo docente é deficiente e o nexo instrução-educação é relaxado (...) ter-se-á uma escola teórica, sem seriedade, pois faltará a corporeidade material do certo, e o verdadeiro será verdadeiro de palavra, ou seja, retórico (Gramsci, 1989, p.131-132).

Complementando seus discursos, conclui que, com a queda verificada no nível do corpo docente, os exames deveriam ser abolidos, porque a correção de julgamento, a análise estética ou filosófica fica prejudicada devido à falta de "bagagem" intelectual dos professores. 
Gramsci defende uma escola ativa, onde a aprendizagem ocorre "por meio de esforço espontâneo e autônomo do aluno", restando ao professor uma função de controle e de orientação amigável. Chega mesmo a preconizar a substituição dos exames pelas atividades em seminários, bibliotecas e laboratórios no liceu ( $2^{\circ}$ grau), de forma a "complementar e a vivificar o ensino oral" (Manacorda, 1990, p. 190).

É na fase do liceu que o aluno completará a sua formação humanística, antes da especialização intelectual (na universidade) ou profissional (na fábrica), desenvolvendo a autodisciplina intelectual e a autonomia moral. Este ensino humanístico, baseado no estudo da história, da literatura e da filosofia, fornecerá melhor base aos estudantes, mesmo no ensino politécnico. Nesta fase o aluno já deverá ter concluído oito anos de ensino elementar e ginasial, restando-lhe dois anos de liceu (idem, p.140el60-161).

Falando sobre os programas e conteúdos curriculares, Gramsci (1989, p. 133) discorre sobre o currículo da "velha escola', de cunho humanista. Seu itinerarium mentis baseava-se no estudo gramatical do grego e do latim. Este princípio educativo almejava

o desenvolvimento interior da personalidade, a formação do caráter através da absorção e da assimilação de todo o passado cultural da civilização européia moderna.

O objetivo a atingir era a formação do intelectual tradicional, do bom orador. Mas, a partir disto, o ensino do grego e do latim permitiria ao aluno adquirir "uma intuição historicista do mundo e da vida", com "a mínima intervenção" educativa do professor. Não que essas línguas possuíssem "qualidades intrinsecamente taumatúrgicas no campo educativo", mas a maneira como o conteúdo se organizasse proporcionaria ao aluno "uma grande experiência sintética, filosófica, de desenvolvimento histórico-real" (idem, p. 134).

Advém daí a dificuldade da substituição desses conteúdos por outros, uma decorrência das mudanças ocorridas na sociedade, na visão do mundo, no desenvolvimento da ciência.

Gramsci reconhece a necessidade de incorporar a ciência ao conhecimento escolar, apesar de seu caráter classista. Para ele, a ciência é uma superestrutura. 
Gramsci (1989, p. 184) procura desenvolver uma concepção de escola cujo pressuposto é a recomposição da unidade entre trabalho e ciência "através da mediação da tecnologia". Essa escola deverá conciliar o novo princípio educativo, que é o princípio da produção industrial, com a transmissão da cultura clássica e moderna, atendendo aos interesse da classe trabalhadora. Partindo da situação da educação italiana, propõe a criação de uma escola única, de caráter utilitarista e humanista ao mesmo tempo, em substituição ao liceu e à profusão de escolas profissionais existentes, as quais cindem o conhecimento e desperdiçam talentos.

\section{A ESCOLA UNITÁRIA}

Com as modificações ocorridas na esfera social após a introdução do princípio da produção industrial, a escola tradicional entra em crise. A incorporação deste novo princípio ao processo educativo, sem acarretar o seu empobrecimento, não é tarefa fácil.

Em primeiro lugar, porque o campo educativo é o campo de atuação, por excelência, dos intelectuais, particularmente na universidade. É por meio dela que a classe dirigente "seleciona elementos individuais de outras classes, a serem incorporados a seu pessoal governativo, administrativo e dirigente". Se ela é burocrática e a sua influência na vida cultural do país é pequena, isto devese ao distanciamento existente entre os intelectuais e o povo. Como a fiação "mais homogênea e mais numerosa" dos intelectuais é a dos professores, é necessário organizar um programa escolar que lhes interesse e lhes dê "uma atividade própria dentro do campo técnico" (apud Manacorda, 1990, p. 119, 124 e 170).

Seguindo a tradição marxista de crítica à profissionalização estrita-e sua consequência à manutenção da "velha e rígida divisão do trabalho -, Gramsci enfatiza os aspectos negativos das escolas profissionalizantes existentes.

Ultrapassando a mera crítica desse ensino, conclui que a escola tradicional era oligárquica, porque destinada a perpetuar "uma determinada função tradicional, diretiva ou instrumental". Para "destruir esta trama", é necessário criar 
um tipo de escola preparatória (elementar-média) que conduza o jovem até os umbrais da escolha profissional, formando-o entrementes como pessoa capaz de pensar, de estudar, de dirigir ou de controlar quem dirige (idem, p. 136-137).

Ou seja, uma escola abertamente democrática, que amplie "a base da camada governante tecnicamente preparada", preservando os "valores fundamentais do humanismo". O objetivo dessa escola é muito mais amplo do que qualquer objetivo educacional.

O advento da escola unitária significa o início de novas relações entre trabalho intelectual e trabalho industrial não apenas na escola, mas em toda a vida social. O princípio unitário, por isso, refletir-se-á em todos os organismos de cultura, transformando-os e emprestando-lhes um novo conteúdo (idem, p.125).

Como se percebe, o objetivo de Gramsci é fazer surgir uma nova organização cultural mediante a reformulação da atual organização acadêmica e da unificação dos "vários tipos de organização cultural existentes, (...) inclusive os militares, integrando o trabalho acadêmico tradicional (...) a atividades ligadas à vida coletiva, ao mundo da produção e do trabalho" (idem, p. 126-127).

Nesse sentido ele critica a defesa de Engels da manutenção do ensino da gramática, do grego e do latim como fulcro da escola humanista moderna, embora valorize os valores humanistas fundamentais de Marx e Engels. Incorpora a ideia da formação teórica aliada à aplicação prática: "educação e trabalho produtivo andarão lado a lado".

Essa ideia, aliás, havia sido defendida também por liberais como Lavoisier e Condorcet durante a Revolução Francesa. Mas Lênin e Kruspskaia as assumem como "elemento teórico de um princípio político", parte integrante do programa do Partido Comunista de 1919.

Instrução gratuita e obrigatória, geral e politécnica, para todos os jovens dos dois sexos até os 16 anos; estreita ligação entre o ensino e o trabalho socialmente produtivo (apud Manacorda, 1990, p. 149-150).

Essas considerações partem da constatação de que a escola dualista tradicional serve apenas para perpetuar as discriminações sociais. Os cursos profissionais acabam frequentados pela classe trabalhadora, enquanto as classes mais favorecidas frequentam as escolas de formação geral, onde recebem uma melhor preparação com vista a seu futuro ingresso numa universidade. 
E o principio da politecnia de todos os cursos de $2^{\circ}$ grau em torno de um currículo propiciador de uma formação geral sólida e de uma preparação lato sensu para o trabalho.

Gramsci acredita que o desenvolvimento global e integral da personalidade só poderá ser atingido mediante a exposição do jovem a múltiplas experiências. Recusa fortemente o espontaneísmo da pedagogia rousseauniana e a atitude ingênua dos escolanovistas na sua tentativa de reduzir a relação pedagógica ao âmbito das técnicas didáticas, como no Plano Dalton. Para ele, a educação é uma luta contra a natureza, travada no âmbito da escola unitária, com o intuito de preparar o jovem "tanto para os estudos posteriores como para a profissão", já que nenhuma profissão "está privada de conteúdos e exigências intelectuais e culturais" (Manacorda, 1990, p. 106,108,137 e 163).

Para ele é dever do Estado assumir certos encargos familiares de forma a permitir aos jovens de todas as classes sociais frequentar essa escola desinteressada de cultura geral. O objetivo pretendido é coibir o seu ingresso prematuro no mercado de trabalho, o qual se dá sempre em condições desvantajosas, além de impedir o prosseguimento de seus estudos até os patamares mais elevados (Gramsci, 1989, p. 121).

\begin{abstract}
A tendência democrática, intrinsecamente, não pode consistir apenas em que cada operário manual se torne qualificado, mas em que cada "cidadão' possa se tornar "governante" e que a sociedade o coloque, ainda que "abstratamente" nas condições gerais de poder fazê-lo; a democracia política tende a fazer coincidir governantes e governados, assegurando a cada governado a aprendizagem gratuita das capacidade e da preparação técnica necessárias ao fim de governar (idem, p. 137).
\end{abstract}

Como se vê, embora fiel à tradição marxista, Gramsci extrapola a herança inicial daquela tradição, vendo na educação o veículo ideal para a democratização de fato da sociedade. Não essa educação que aí está, dualista, viciosa, discriminatória. Partindo da constatação do caráter classista e injusto da educação e das necessidades advindas das esferas produtiva e científica, propõe um modelo de escola no qual as diferenças de classe são diluídas por um currículo baseado nos valores humanistas e nas qualidades essenciais requeridas pelo mundo da produção industrial. 
Dessa escola deverá emergir o cidadão completo, participante, governante ou governado, mas consciente de sua função e importância no âmbito da sociedade, dos direitos e deveres da cidadania, menos competitivo, mais produtivo, tendo seus talentos valorizados e compreendidos, pois a vida social supõe a multiciplicidade de talentos e aptidões. Se não, como preencher as diferentes funções exigidas pela vida moderna? Negar a esta ou àquela classe $o$ reconhecimento de que ela é parte integrante da sociedade em todos os seus níveis é negar o princípio democrático básico da igualdade. Pior ainda, é desperdiçar o talento e a habilidade de pessoas que talvez pudessem contribuir significativamente para a solução dos problemas oriundos da organização da produção e da própria vida em sociedade.

\section{Conclusão}

A sociedade capitalista ocidental moderna avoca para si o mérito de respeitar os princípios democráticos apregoados e difundidos após a Revolução Francesa. O estudo de uma das suas instituições básicas - a escola - revela, entretanto, que a adesão a esses princípios é feita em nível formal, apenas. A escola moderna, conquanto seja bem menos elitista que a escola medieval, por exemplo, continua incorrendo em alguns de seus erros mais comuns.

Primeiramente, ela não se universalizou de fato, pelo menos, não nos países do Terceiro Mundo. E mesmo naqueles países que conseguiram eliminar o analfabetismo e proporcionar à totalidade da sua população uma educação básica, ela continua reproduzindo as classes sociais diferenciadas, conforme a origem social de seus alunos. Aqueles provenientes das classes que detêm o poder econômico encaminham-se "naturalmente" para os cursos de estudos superiores; os demais, para os cursos técnico-profissionalizantes ou simplesmente para as ocupações manuais não-especializadas.

Marx e Engels puderam observar essa tendência perversa da educação e a denunciaram. Foi o ponto de partida para muitos estudiosos e serviu de parâmetro até para aqueles que não comungam com suas idéias. Entre tantos que estudaram o tema, sobressai o pensador italiano Antônio Gramsci, cuja obra não se limitou à denúncia do caráter antidemocrático da instituição escolar. 
Partindo, na palavra de seus mestres, da "situação atual" da educação de seu tempo, propôs uma completa reformulação da instituição educativa, que é perfeitamente atual e válida em nossos dias.

A mais brilhante contribuição gramsciana à educação virá do desdobramento da tradição marxista de combinação da educação humanista tradicional com a educação politécnica. Sua proposta da escola unitária vai além do simples ensino técnico tradicional. Nisto ele incorpora a crítica marxista ao profissionalismo estreito, que só contribui para desvalorizar o trabalhador e diminuir seu valor no mercado de trabalho. A formação da escola unitária deverá preparar o cidadão para exercer qualquer cargo no futuro, seja este de operário ou de dirigente, rompendo o círculo vicioso de perpetuação das mesmas elites no poder indefinidamente, com base no argumento do melhor "preparo" intelectual.

A formação politécnica, além de respeitar as inclinações e aptidões do aluno, representa uma democratização real da sociedade, culminando na diluição das diferenças de classes e na cidadania plena. Desaparece o cidadão "de segunda", analfabeto ou semi-alfabetizado, o operário manual que desconhece o princípio do trabalho, aquele que participa do processo político da escolha dos dirigentes apenas como um número, a "massa de manobra".

Pois, uma sociedade verdadeiramente democrática é formada por cidadãos conscientes, que participam de fato das decisões tomadas pela elite dirigente, e cuja opinião é ouvida e respeitada e cujo consentimento é buscado. Uma organização escolar que não adira a esse princípio será apenas formalmente democrática. Mas não será, de fato, uma escola desinteressada, no sentido gramsciano do termo, capaz de formar tanto o operário especializado quanto o dirigente político.

Eis aqui, resumidamente, a essência da contribuição de Marx, Engels e Gramsci para a filosofia da educação: o princípio democrático radical da escola. Uma escola unitária, ultrapassando a clássica dicotomia entre conhecimento teórico e conhecimento prático que permeia a organização escolar ocidental desde os seus primórdios. Somente uma escola unitária poderá traduzir, na prática, o princípio democrático da educação moderna, caracterizando-a como praxis. Cabe, agora, aos educadores progressistas transformar essas categorias em modelos, projetos e programas a serem implantados, discutidos, avaliados, vivificando-as e não permitindo que caiam no esquecimento. $\mathrm{Ou}$, pior ainda, que sejam apropriadas e desvirtuadas pelos setores conservadores da sociedade. 


\section{Referências bibliográficas}

ENGELS, Friedrich. Anti-duhring. Lisboa: Mineira, 1975a.

. Princípio do comunismo. In: MARX, K., ENGELS, F. Crítica da educação e do ensino. Lisboa: Moraes, 1978.

. A situação da classe trabalhadora na Inglaterra. Lisboa: Presença, 1975b. 447p. (Síntese, 22).

GRAMSCI, A. Americanismo e fordismo. In: Maquiavel, apolítica e o Estado Moderno. Tradução de Luiz Mário Gazzaneo. 3.ed. Rio de Janeiro: Civilização Brasileira, 1978.

. Os intelectuais e a organização da cultura. 7.ed. Rio de

Janeiro: Civilização Brasileira, 1989.

MANACORDA, M.A. O princípio educativo em Gramsci. Porto Alegre: Artes Médicas Sul, 1990.

MARX, K. Conselho Geral da A.I.T., 1869. In: MARX, K., ENGELS, F. Crítica da educação e do ensino. Lisboa: Moraes, 1978a.

Os fundamentos da crítica da economia política n. In: MARX, K., ENGELS, F. Crítica da educação e do ensino. Lisboa: Moraes, 1978 b.

. A guerra civil na França. In: MARX, K., ENGELS, F. Obras escolhidas. São Paulo: Alfa-Ômega, [19—?]. v.l. . Instruções aos delegados do Conselho Central Provisório, ATT, 1968. In: MARX, K., ENGELS, F. Crítica da educação e do ensino. Lisboa: Moraes, $1978 \mathrm{c}$.

. Salário, preço e lucro. 5.ed. rev. ampl. São Paulo: Global, 1987.

89p.

MARX, K., ENGELS, F. O capital. São Paulo: Difel, 1985. 
. Crítica da educação e do ensino. Lisboa: Moraes, 1978.

. Obras escolhidas. São Paulo: Alfa-Ômega, [19-?]. v.1.

. Textos sobre educação e ensino. São Paulo: Moraes, 1983.

Bibliografia: p. 21-25, 39-40,60,65,68-70,81,90-98.

TESES sobre Feuerbach. Tradução J. A. Gianotti. In: MARX, Karl. Manuscritos econômico-filosóficos e outros textos escolhidos. [S.1.]: Abril Cultural, 1974. (Os pensadores, v.35).

Recebido em 2 de agosto de 1996.

Lilian Maria Paes de Carvalho Ramos, doutoranda em Educação pela Universidade Estadual de Campinas (Unicamp), é professora assistente da Universidade Católica de Petrópolis-RJ.

The basic démocratie principies ofeducation in the works ofMarx, Engels and Gramsci are discussed in the paper. Some ofthose principies were supported by authors with different ideological tendencies and purpose. But the ideas focused here, particularly that of polytechnical education, aim not only at the refinement of labor preparation for the new industrial society through schooling processes. They aim, above ali, at the edification of an hegemony of the working classes and its direct consequence: the democratization ofthe ruling classes.

On se centre dans 1'étude du príncipe d'education politechinique, pas seulement comme source deformation de main d' oeuvre reclamée par la societé industrielle, mais comme construetion d'une hégémonie de la classe travailleuse et, par conséquent, Vaceroissementprécis des endroits participatifs de la démocratie. La base du travail sont les príncipes démocratiques de l 'education inclus dans diverses produetions de Marx, 
Engels et Gramsci, et soutennus par des auteurs qui, avec divers objectifs et diferentes idéologies, travaillent la thématique.

Centrando el estúdio en el principio de educación politécnica, no solo como recurso deformación de mano de obra requerida por la sociedad industrial, sino como construcción de una hegemonia de la classe trabajadora y, por conseguiente, la ampliación concreta de los espacios participativos de la democracia. Basando el trabajo en los princípios democráticos de la educación quefiguran en diversas producciones de Marx, Engels y Gramsci, defendidos por autores que, a partir de diversos objetivos y desde distintas posiciones ideológicas, abordan la temática. 